\title{
The Peculiarities of Forming Rural School Students' Healthy Living Skills after Shool and in Extracurricular Work by the Use of Information Innovation Technology
}

\author{
Daniarov Talgat ${ }^{1}$, Bazarbaev Kanat ${ }^{1}$, Nyshnova Saltanat ${ }^{1} \&$ Myrzakhanova Akbota $^{1}$ \\ ${ }^{1}$ A. Yasawi International Kazakh-Turkish University, Turkestan, 161200, Kazakhstan \\ Correspondence: Daniarov Talgat, A. Yasawi International Kazakh-Turkish University, Turkestan 161200, \\ Kazakhstan. Tel: 7-775-647-6873. E-mail: shakarim08@mail.ru
}

Received: August 11, 2012

Accepted: August 17, 2012 Online Published: September 26, 2012

doi:10.5539/ies.v5n6p90

URL: http://dx.doi.org/10.5539/ies.v5n6p90

\begin{abstract}
If we turn to the educational views and ideas in the history of education, we see that the goals of education have an active and changeable specific historical characteristics. Specifying its state policy and ideology determine the social needs, based on natural, social and human development of objective laws. In this structure, there is a need complies with the requirements of society development level of productive forces and relations of production quality, the pace of scientific and technical progress, economic opportunity society, the level of development of educational theory and practice of educational opportunities, the level of development of educators and teachers. Analysis of different definitions lead to the conclusion that innovation is a substantial change, and the main feature of innovative change - this is a function of the change. The innovation comes at a time when educational problems can not be solved by traditional forms, creating the need for new technologies in line with new goals and objectives. Despite the fact that the traditional and innovative educational technologies have differences, it does not mean that their unity should be considered separately. They have some inherent characteristics, but objectively they have common characteristics that bind them together. In order the teacher could effectively carry out the objectives and tasks of education and training, it must be based on the characteristics of each use of educational technology and adequately understand the meaning and essence of their relationship with each other.
\end{abstract}

Keywords: healthy living skill, technology, extracurricular activity, healthy lifestyle, innovation

\section{Introduction}

The purpose of education in secondary schools is to provide intellectually, moral, emotional and physical development of the individual; the disclosure of its creative possibilities, and the formation of friendly relations, given the age of the younger generation - to create conditions for the education of individuals. Thus, for the goal to meet the special requirements of the organizers of educational and extracurricular activities, content and methods of their work is necessary. Kazakh scientists who gave a scientific description of the educational work based on folk traditions and principles, among whom K.B.Zharykbaev (Jarykbaev \& Kaliev 1995), S.A.Uzakbaeva (Uzakbaeva,1995), K.Zh.Kozhahmetova (Kojahmetova,1993), A.Tabyldiev (Tabyldiev,1991), A.Ashaiuly (Ashayiuly,2002), etc. in their work revealed not only the theoretical foundations of national pedagogy, but also the practical aspects of the development of educational work in schools, ways to improve the educational process and its features.

In 1975 S.Eshimhanova's research work called "Patriotic education of students in extracurricular time in the Great Patriotic War." was published. The paper presents the content, forms and ways to develop patriotism among students. Objectively, the most common forms of extracurricular activities are extracurricular activities, clubs, educational hours, laboratory work, weekly classes, conferences, competitions and seasonal events. Among the requirements for extracurricular educational work, we can mark the following:

1) The scope and involvement of all students into extracurricular activities

2) Accounting requirements and desires of each student

3) Knowledge of personal characteristics and talents of each child

4) The development of creative abilities 
5) Organization of public events Extra-curricular work is carried out under the immediate start of the school principal or a teacher. The effectiveness of extra-curricular work depends on the proper organization of the student.Kazakhstani scientists S.Amiraliev, K.Seytaliev (Amiraliev \& Seytaliev, 1983), K. Kunantaeva (Kunantaeva, 2005), etc. in their works separately dwell on the peculiar characteristics and types of extracurricular activities.

Sh.Amiraliev in "unity of education and training," suggest that a positive result in the educational work can be obtained only through the unity of academic and extracurricular activities. In K.Kunantaeva's work of 'Association of students in extracurricular time, "affecting the form of extra-curricular educational work and its place in the education of the younger generation, the analysis of extra-curricular work, which includes the introduction of students to the great personalities of the people, the epistolary genre, visiting museums and famous places organization of competitions and meetings with famous people, preparing students for the correspondence of the organization and the lecture. Methodological, theoretical foundations of extracurricular educational work in schools more fully described in A. B. Baynazarova's (Bainazarova,1982), T. K. Zhumazhanova's (Jumajanova,1996), S.G.Tajibaeva's papers (Tajibaeva,2007). In M.Sadykova's research work on the basis of archival materials of 1940-1960 yy. given the historical and pedagogical systematization of the historic foundations of the level of general extracurricular activities in the country, the development and use of its modern form (Sadykova,2002). Researcher E.O.Omar who made contributions to the elucidation of the question of organizing of extracurricular activities, collected and systematized experience of extra-curricular activities of educational institutions of Kazakhstan for 1917-1980 years (Omar, 2002). Received the historical experience of extracurricular activities became the determining direction for our research. The school experience of extracurricular activities in our country is in two directions, divided into two separate subjects: extra-curricular educational activities and class work. In the system of education of school and extracurricular features educational work is determined by personal characteristics of children and their age. The purpose of extracurricular educational work is to complement and expand the educational problems in the classroom, the maximum disclosure of students' abilities, encouraging their interest in the environment, social activism, organizing their free time. In the educational encyclopedia this activity is characterized as "extra-curricular educational activities organized after school.

Table 1. Structural components and extracurricular educational work

\begin{tabular}{ll}
\hline $\begin{array}{l}\text { The components of } \\
\text { extracurricular activities }\end{array}$ & The structural elements of extracurricular activities \\
\hline Person-group component & $\begin{array}{l}\text { 1. The head of the class } \\
\text { 2. Organizer of extracurricular activities } \\
\text { 3. Parents of the student }\end{array}$ \\
& 4. Students involved in the educational process and the daily activities of the class \\
Substantial component & $\begin{array}{l}\text { 1. Aims and tasks of extracurricular activity } \\
\text { 2. Content of extracurricular activity }\end{array}$ \\
Effective components & $\begin{array}{l}\text { 3. Structure of the educational system } \\
\text { 2. Forms and methods of organizing relationships and joint action }\end{array}$ \\
& 3. Students self-control and pedagogical supply of the process
\end{tabular}

One of the inseparable parts of educating skills of healthy lifestyles is sex education of the younger generation. Currently, sex education for young people has become an urgent task. This is confirmed by the negative effects of modern life: an increase in gynecological and sexually transmitted diseases, the entry of young people in sexual relations at an early, still has not reached the physiological and psycho-sexual maturity and age.Among the psychological and pedagogical conditions of the educational process in the formation of healthy way of students life at the out school time clearly traced the separation of the personal conditions of the organization process, as they provide part of the individual in self-education of healthy living habits. To save them the coach, firstly to participate more actively in the rational organization of work and rest regime, and secondly, it is very 
important for a healthy lifestyle to develop students' reflective skills that contribute to the expansion of their social relationships, and develop their ability to properly and objectively to establish self esteem. All this provides healthy interpersonal relationships. It should be pointed out that the person is not analyzing a process, who is exposed to the environment and society, but, he is an active element in this structure. This direction is justified by S. Rubinstein. The efficiency of forming a healthy identity depends on the internal workings of the education of her passions, and directions.The introduction into the teaching area of the concept of "technology" was founded with the idea of "industrial" technology (F.B.Gilbreyt, F.U.Teylor, etc.) and is associated with the use of technical equipment in the training. In the educational field of educational technology is aimed at the technique of analysis of the organization of the teacher (T.A.Ilina), in other words, to achieve maximum effect with minimal force. Thus, the educational technology form a network that positively affects the development of the student.Before you use the term "new teaching technologies," to learn its meaning. To do this we first need to familiarize ourselves with the concept of "technology" and the sphere of its application.

Technology - from the Greek techne (skill mastery) and logos (science knowledge). In foreign dictionaries "technology" - a set of institutional arrangements, operations and techniques to manufacturing, service, repair, operation and / or disposal of the product (object technology) rated the quality and economic cost, and due to the current level of development of science, technology and society as a whole.S.Ya.Batyshev in his work gives several definitions of the concept of "technology" in relation to the pedagogical process: Technology - the art, skill, efficiency, ability to change the circumstances, a combination of methods of treatment.Technology - the cultural concept which relates to thought processes and human activity. Technology - Intelligent processing of significant technical qualities and abilities. Technology - a body of knowledge on how to implement these or other processes. Technology - assimilated with the educational process, purposeful and planned pedagogical influence and activities. Technology-Technology meaningful implementation of the educational process.Technology is a mechanism to ensure the achievement of educational goals. Technology - characteristic of the process leading to the planned learning outcomes. Technology - project specific educational system, implemented in practice. P. R. Atutov V. A. Polyakov and believe that "technology (process technology) - the bulk of the production process. In this sense, technology is the production, processing, refining, transportation, etc., production and technical control, and thus characterization of manufacturing processes and instructions for their implementation ... ", thus argue that the scientific subject matter deals with the technology obtaining raw materials, design and development of methods and ways of handling and processing (Atutov, 1985).V. P. Bespalko one of the first gave definition to educational technology. He identified the practical application of technology pedagogical as a real educational system (Bespalko, 1989). V.P.Bespalko presented the structure of any educational system as a combination of the following: 1 - the teacher (tutor), 2 - the goal of education (public and private), 3 - content of education, 4 - educational processes (private education and training), 5 Teacher (or ITO - tools and technical training), 6 - forms of organization of educational work, 7 - learning outcomes. He considers the educational system as a set of specially organized, interconnected, target elements that influence the formation of personality. I.P.Podlasy proposes the elements of technology management (Podlasy,1999).To make changes to this or that element of the educational system needed restructuring of the remaining elements.Upgrading educational innovation can be considered as the reconstruction of knowledge, as a material idea, action, form, method, mechanism, concept, program, as the definition of the use of materials. Three types of innovation are shown: ideas and actions are completely new and special, extended, or retrained ideas and actions, pedagogical innovation, updating actions that are planned in the future under the new conditions in spite of the tightening of these or other purposes.

The concept of "innovation" - is not only the creation and distribution of something new, it is actually an active change in action and thought. That which we call the innovation process in teacher upgrading is the unity of the individual parts of pedagogical renewal, development and use of the experience. Innovative processes in education - a system of changes that are directly related to social changes. Their development is important firstly to the formation of an order determined by the society, and secondly, the objective conditions for the update, and thirdly, the ability to accept and carry out this order available team, and fourthly, it is important for the preparation of scientific and managerial innovation. Very important for us to prove the results of the study, because innovation provides a deeper understanding of the complexity and ambiguity of the phenomenon. This understanding defines innovation as the aggregate effect of the subjects. Most researchers consider innovation as one of the most important aspects in the development of modern educational institutions. Any interpretation of the wording makes the meaning of innovation in the content changes, but the main feature innovation - change remains unchanged. The innovation comes at a time when educational problems can not be solved by traditional forms, creating the need for new technologies in line with new goals and objectives. In rural schools the skills of a healthy lifestyle during extracurricular time, most notably as a result of special educational practice, 
experimental work by applying a specially designed innovative technologies and methods for their implementation. The structure of educational technology consists of a substantive and a procedural component. Form a substantial component of tools such as conceptual - a means to an end, a system of knowledge about the effectiveness of the educational process, diagnostic - Vocational Teachers face the teacher, individual personality and level of training of students, teaching - learning content, methods, and instructional techniques, forms of organization ; didactic means. The procedural component being incorporated into the practice of pre-planned educational process, aimed at organizing and managing the activities of students in the educational process.As the teacher provides the effect of educational technology, its contents consisting of teacher effects: finding teaching language, teaching, assessment, teaching talent, information and demo-linguistic influence. The specific functions are defined in accordance to the operation keys, run the data elements that make up the value of educational technology, providing knowledge, having a necessary and sufficient professional sense for the impact on the subject of the educational process of the teacher - pupil. However, the content of educational technology that is not limited to: additional elements - the psychological climate and group activities, teacher reaction to the actions, the organization of the environment, etc. possessing a common characteristic or private, are part of the action for the conservation of the independence of each teacher and enliven the forms of influence. Pursuing research in this field, we set the goal to identify ways and opportunities to use innovative teaching technologies in the development of healthy living habits of students. Depending on the nature of the use of educational technology can be divided into traditional and innovative. Let us consider in more detail on their differences. Innovation ("innovation" - a new and innovative, the suffix "In" means "repeatable" process, a phenomenon changes) - indicates the emergence and development of something new in some of the manufacturers or other action. This concept is often corresponds with the concepts of "the introduction of a new," "creating a new," "reform," but in a broader sense, means any change in the system.

Traditional technologies have experienced the test of time, and therefore proved its viability and effectiveness, and discard them would be a big mistake, and innovative technologies have arisen in consequence of the requirements of modern times and answering inquiries, too, proved to be necessary in the educational process.

As a necessary condition for the implementation of innovative technologies, scientists K.Kabdykayyruly, V.M.Monahov, etc. believe it is important to draw attention to the following enforceable methodological principles:

1) The principle of trust in the professional teaching abilities of the teacher.

2) The principle of the harmony of the interaction of traditional sources of training with the elimination of regressive and limiting factors in the school.

3) The correspondence principle is correct and true information in the educational establishment and use of technology and training organization.

4) The principle of the unity of the harmonious development of relations between teachers and pupils in the educational process.

5) The principle of the unity of content, system and motivation of the parties in the design of new technologies (Tretyakov,1997).Based on the foregoing, we believe it necessary to submit a proposed classification of innovative educational technologies, and give each of them a meaningful response. The main criteria in establishing the classification served as a program separate from the possibility of their educational process.The content of the classification form a name, the main essence of technology and educational opportunities. Using the technology of each teacher has the ability to relate technology with the content of educational work.

Now we give a meaningful description of educational technology, specified in the classification. Professionally designed technologies make it possible to organize the educational process taking into account the personal guidance of students. The basis of the creation of such a technology created by the governing design guide of the teacher and the student work effectively. As the main source of the design professional is taken towards technology training and professional qualifications with regard to the purpose and content of the training of educational work. At the same time we should not forget about the positive aspects of personality and its creative possibilities. 
Table 2. Classification of innovative technologies, presented for the formation of students healthy living habits

\begin{tabular}{ll}
\hline $\begin{array}{l}\text { Pedagogical innovation } \\
\text { technologies }\end{array}$ & Fundamental importance \\
\hline $\begin{array}{l}\text { 1. Professionally designed } \\
\text { technology }\end{array}$ & $\begin{array}{l}\text { System of interaction of the teacher and student, aimed at developing } \\
\text { interest, skills and talents of students from their account in the pedagogical } \\
\text { process }\end{array}$
\end{tabular}

2. Problem-solving training

3. Structural and logical.
Didactical system directed to the educational problems and situations, using the heuristic method of teaching

System, aimed at ensuring logical systematic formulation and solution of problems on the basis of a consistent and gradual organization of educational process, harmonization, and the selection of content, forms, methods and means of educational work for each phase of the periodic diagnostic results.

\section{Game technology}

\author{
5. The training \\ 6. Computer Technology
}

7. "Case-technology"
Educational measures aimed at the use of different games directed to the solution of educational challenges

\section{System of activities aimed at solving specific problems}

Information system, linked to organizing healthy lifestyle and aimed at obtaining, processing, transportation, storage and use of information through computers

Teaching and educational technology, implemented through the use of real educational situations

The important characteristics of professional directional technology are: performance, achieving high performance by each of the students; economy, the most efficient use of materials with less efforts of teacher and student for a unit of time; psycho hygienic implementation of the educational process in an atmosphere of friendship, mutual cooperation and a positive emotional climate in such situation will not be over-energy and fatigue.This technology makes extensive use of the principles of person-oriented and other scientific areas: equal educational partnership aimed at addressing the communicative and cognitive tasks, taking into account psychological characteristics of students, formation of their identities, ensuring the development of each student as an individual, a variety of means and methods of learning; relationship of the subject with feelings, emotions, experiences and real life; to interest not only students but also teachers, satisfaction of both parties (Pidkasistyi,1996).Structural and logical technologies, designing an integrated system of teaching and educational process aimed at creation of the educational process to achieve this goal, the creation and selection of systems analysis and definition for the teacher and the projected results obtained, a system works to prevent and correct possible mistakes and difficulties encountered in working with students (Paronova,2003).Information technology is a method and means for receiving, processing, delivery, transfer, preservation and use of information and data (Levina,2001). The purpose of the use of information technologies in educational process providing students immediate and reasonable training and education, the achievement of planned quality education.Problem-solving training, complies with its content and structure, is a technology teacher education by the classification of the creative processes of the teacher and students. It differs from other types of technology firstly, that the whole structure of the learning activities are functionally valid, and secondly, the advantage that gives opportunity to regulate activity itself, that is, the steps for creating a model of learning in a problem and solution methods are carried out independently of the subject.

At the moment the problem teaching is one of the key technologies, offering humanized direction of pedagogical science and practice. Its base forms the idea of creating an innovative environment that have a particular impact on teacher professional development (Reshetnikov,2000).Objectively, the use of technology problem-based learning enhances independent innovation as a teacher and student. Another technology, which has future development is a "case-technology" (learning through the use of real-world learning situations).

Implementation of the technology "case study" includes the following steps: Stage 1. A teacher, looking at the text describing the situation, to understand the meaning of the problem, determine the approach to the 
assessment of the situation, consider the answers to questions and to identify practical ways to solve the problem.Stage 2. Working in small groups. In a small group (4-6 people) is an exchange of views on the issues that form the basis of case study, carried out a joint search for solutions to problems through bilateral dialogue. For this purpose the "brainstorming" - brainstorming, dialogue, discussion, debate, etc. After the panel discussion, a decision on the issue is announced by the most experienced representative of the group.Stage 3 . Common group discussion takes place on the guidance of a teacher or tutor. According the rules, each group expresses their ideas on the situation in the presented problem. The teacher, guiding the process of analyzing the situation, the discussion draws as many students, trying to discuss as many opinions and ideas and trying to awaken their creative home. The peculiarity of the discussion - the teacher does not give a qualitative assessment of the answers."Case" technology can be used in teaching any subject or educational work. The real situation doesn't give either right or wrong answer; it is an educational material to teach students in the analysis, public speaking, art, debate, and unconventional thinking. Types of innovative technologies presented above, are particularly effective in the educational process of today's rural schools, as they provide an opportunity to achieve effective results by integrating traditional and innovative educational measures. At the same time, these technologies have the pedagogical humanistic character in terms of philosophical, psychological, pedagogical, and in developing healthy lifestyles of students, their liberty and morality. Another important aspect of a healthy lifestyle is the intellectual aspect. It represents the students social experience gained by previous generations, describing the history of studies of healthy lifestyles. This task is implemented by teachers familiarize students and repose of the human body, mechanisms of its development, and positive or negative factors affecting this process: physical activity, tempering, smoking, alcohol, drugs, that is attracting students to a healthy lifestyle through public art, directed to investigate the influence of nutrition and the negative consequences of using negative factors.

The formation of a healthy lifestyle aspect of personality has a different introduction to the student or pupil self-knowledge, his personal interests, abilities and capabilities. In solving the problems other than learning students need to attach to the games, communicate, work and various types of creativity. This is accomplished through a variety of school clubs, studios, laboratories, enabling the development of independent creative personality.The social aspect of a healthy lifestyle offers students the development of their human values. How differentiated microenvironment was not a student, it shall enter into certain relationships (family, communication with the teacher, friends, community and educators, etc.) is not only develops a personal attitude, it makes it so who he is, developing his personality. Thus, we gave an overview of opportunities for healthy lifestyle of students through new pedagogical techniques. New technologies -means that empower teachers, but they can not replace a teacher himself. Computer capabilities, passing the psychological and didactic analysis, if necessary, should be used in accordance with the requirements of teaching. The goal is not an external effect, the training program must have an internal efficiency.Using information and communication technologies in educational process makes it possible to implement the following educational opportunities: -Organization of learning and using new information technologies in the learning process taking into account the level of training of the student, his zeal, interest and ability to learn the material;-New methods and forms of learning (problem method, organization and an active computer games,etc.);-Improvement through the use of classical methods of modeling the problem, research and analytical methods;-Development of material base technical learning process through the use of new information technologies (computers a new sample, telecommunications, virtual environment and multimedia technologies).

Using information and communication technologies in educational process in solving problems to improve the skills of experts provides the following features: -Meet the needs of educational institutions for specialists in the formation of information and cultural elements: the generation of new knowledge in the field of computer science, information and network technologies;-Training and retraining of teachers of science; -Training of administrative personnel of the education system and teachers for subject-free use of new information technologies in the sphere of its activity; -Organizing and conducting training of teachers of computer science on topical issues of learning the subject of computer science;Orientation of teachers on distance learning; -Coordination of scientific-methodological direction of informatization of educational institutions;-Formation of a unified educational information resources of the network; -Dissemination of best practices of the educational process and scientific and methodological activities through the use of new information technologies in this field.

For the development of this direction for education it is necessary to send employees to conduct various trainings and courses, which requires first the establishment of appropriate systems and making the curriculum, taking into 
account the particular categories of workers in education. This question has become one of the most pressing issues today.

At present, information and communications teacher competence has become an integral part of the structure of professional specialty. So the question is relevant to the preparation of future teachers and should include the following: What are the stages of information and communication competence? What is the meaning and content of the formation of information and communication competence? To what level can generate information and communication competence? Formation of information and communication competence in higher educational institutions can be divided into three phases, which together with the main characteristics are presented in Table 3 .

Table 3. Stages of formation of ICC in the preparation of professionals and educators

\begin{tabular}{|c|c|c|c|c|}
\hline № & $\begin{array}{l}\text { Name of } \\
\text { stage }\end{array}$ & $\begin{array}{l}\text { Subjects studied and } \\
\text { the period }\end{array}$ & studied the knowledge and skills & $\begin{array}{l}\text { characteristic features of } \\
\text { phase апа }\end{array}$ \\
\hline 1 & $\begin{array}{l}\text { A base - the } \\
\text { formation of } \\
\text { the basic } \\
\text { ICC. }\end{array}$ & $\begin{array}{l}\text { High School } \\
\text { "Computer" and / or } \\
\text { "Information } \\
\text { Technology" }\end{array}$ & $\begin{array}{l}\text { The general concept of computer } \\
\text { devices. Basics of the operating system. } \\
\text { Create simple documents Word. } \\
\text { Keeping simple accounts on Excel. } \\
\text { Creating simple presentations. }\end{array}$ & $\begin{array}{l}\text { Use of IT in the } \\
\text { organization of } \\
\text { educational activities of } \\
\text { teachers of the school. } \\
\text { Solution of simple } \\
\text { household tasks. }\end{array}$ \\
\hline 2 & $\begin{array}{l}\text { Total - } \\
\text { forming a } \\
\text { common } \\
\text { ICC }\end{array}$ & $\begin{array}{l}\text { 1-2 courses of higher } \\
\text { educational } \\
\text { institutions. } \\
\text { "Computer" or } \\
\text { "Computer Science } \\
\text { and Mathematics }\end{array}$ & $\begin{array}{l}\text { "Searching for information through } \\
\text { Internet resources. Create a simple } \\
\text { (without figures and tables) and } \\
\text { complex (with drawings, graphs and } \\
\text { tables) of documents Word. The } \\
\text { calculation formulas, conducting } \\
\text { mathematical, logical and statistical } \\
\text { functions in Excel. Creating charts. } \\
\text { Create a database (single and } \\
\text { multi-table) and queries, forms and } \\
\text { reports in the database. }\end{array}$ & $\begin{array}{l}\text { The use of information } \\
\text { technology in the } \\
\text { preparation of seminars, } \\
\text { workshops, writing } \\
\text { articles, theses and term } \\
\text { papers, as well as in the } \\
\text { preparation of } \\
\text { presentations at scientific } \\
\text { conferences }\end{array}$ \\
\hline 3 & $\begin{array}{l}\text { Professional } \\
- \\
\text { development } \\
\text { of } \\
\text { professional } \\
\text { ICC }\end{array}$ & $\begin{array}{l}\text { 4-3 higher } \\
\text { educational } \\
\text { institutions. } \\
\text { "Technical and } \\
\text { audio-visual } \\
\text { teaching aids", } \\
\text { "Information and } \\
\text { technical support } \\
\text { training," } \\
\text { "Information } \\
\text { technology } \\
\text { education," etc. }\end{array}$ & $\begin{array}{l}\text { Using the resources of the Internet in } \\
\text { search of information. Making } \\
\text { educational policy documents and the } \\
\text { use of text processes in the material } \\
\text { organization of the educational process. } \\
\text { Using the graphics processor in a } \\
\text { ranking system evaluation and } \\
\text { establishment of computer tests. } \\
\text { Creating a database system to account } \\
\text { for the results of school teachers. The } \\
\text { use of special tools, the creation of } \\
\text { computer-based tests. }\end{array}$ & $\begin{array}{l}\text { Using the application } \\
\text { software to create personal } \\
\text { online resource of } \\
\text { information and } \\
\text { communication technology } \\
\text { production and } \\
\text { pedagogical } \\
\text { solving responsibilities. }\end{array}$ \\
\hline
\end{tabular}

Informatization of education - a process of research methodology and experimental values of the use of ICT tools in education and provision of education and training in psychological and educational purposes.

In the literature, we often meet the terms "information competence", "computer competence". Due to the rapid development of information and communication technologies, the most effective would be to use the term "information and communications expertise." Information and communication competence is a person's ability to solve various problems and challenges through the computer, information and communications mechanisms. Professional development in teacher education, informatization has become one of the major challenges of our time. There is therefore a need to establish educational and thematic plans, standards and concepts of 
information professional development of teacher. From this perspective, the use of information technology in the formation of healthy living habits is of particular importance.

\section{Conclusion}

It should be recalled that in the pedagogical, methodological, medical, biological and psychological literature, the issue of promoting a healthy lifestyle devoted a great deal.

However, as a result of healthy lifestyle factors were considered separately, without taking into account the linkages between them, apart from the world of social media, creating a healthy lifestyle, again without regard to social conditions. It is difficult to classify and show the main and additional factors of a healthy lifestyle, because they affect the formation, development and protection of human health complex. The image of modern life depends on how serious it relates to their health, as the singular values. Therefore, the establishment of appropriate rules and regulations of health and healthy lifestyles is an important area full recovery of the society than ever before need to be formed in a healthy way of life, the sooner the habit will be formed and harmonious healthy life skills.As the subject of educating a student is a person, regulating the public consciousness, the spirit and the incentives shaping his character, consciously creating your character and behavior. Step by step, under the necessary and different circumstances, relationships, and analyze their own behavior are formed personal characteristics, qualities and life principles. There is a possibility to set specific goals for self-development and self-conscious. Growing student is gradually increasing through the creative, social, intellectual and emotional activation and conscious of entering into social relations. It was during this period, when formed and develops student's personality, just formed the need to maintain standards and rules of healthy lifestyles, protecting health and development, which will be with him all his life. Wide dissemination of information and computing facilities in the community seriously affects the learning process and change the content of education. The main subject of the reorganization of the education system is the teacher. Modern school requires teachers with advanced capacity for creative search, sufficiently mastered the new teaching technologies and formed a professional skill. Such a teacher should be a teacher and a psychologist, and technology - the organizer of the learning process. If we analyze the issues in the light of computer training opportunities, the fundamental psychological and pedagogical theories of learning generates new psycho-pedagogical and methodological issues.

The need for a healthy lifestyle is associated primarily with the real participation of people from different social backgrounds and different places of residence in the organization of their health. This is shown by numerous facts recorded in printed publications, scientific papers and statistical information.

In health and bright future of the people of our country's current situation of the younger generation plays a major role in the development of its labor potential. Consequently, health care for children and students is a priority for the state. For this reason, the process of informatization of education poses of subject teachers, facilitators, managers of educational institutions heavy demands on the full use of new technologies in the sphere of its activity.

\section{References}

Bainazarova, R. (1982). Effectivnost sovmestnogo obucheniya. p. 16. Almaty.

Bespalko, B. P. (1989). Slagaemye pedagogicheskoi tehnologii. p.192. Moscow.

Jarykbaev, K., \& Kaliev, C. (1995). Kazahskoe vospitanie. Publishing house «SanaT». p. 352 Almaty.

Jumajanova, T. K. (1996). Nauchno-metodicheskie osnovy razvitiya poznavatelnyh navykov po literature $u$ uchashisya vo vneklassnoe vremya. Dissert. candidate. ped. Sciences, p.14. Almaty.

Kunantaeva, K. K. (2005). Istoriya kazahskoi pedagogiki. p.215. Almaty.

Levina, M. M. (2001). Tehnologii professionalnogo pedagogicheskogo obrazovaniya. p. 272. Moscow Academy.

Paronova, S. (2003). Igrotehnologii I socializaciya. Vysshee obrazovanie v Rossii, 5, 74-81.

Pidkasistyi, P. I. (1996). Tehnologiya igry v obuchenii i razvitii. p. 268. Moscow.Ros. ped. Agenstvo.

Podlasyi, I. P. (1999). Pedagogika. Novyi kurs uchebnic stud. Ped. vuzov: B 2 book. p. 576. Moscow. Gumanit. izd. Centr VLADOS, Kn. 1: Obshie osnovy. Process obucheniya.

Reshetnikov, P. E. (2000).Netradicionnaya tehnologicheskaya sistema podgotovki uchitelei: Rojdenie mastera. p. 304. Moscow. Centr VLADOS.

Sadykova, M. K. (2002). Razvitie vneklassnoi vospitatelnoi raboty prepodavatielei kazahstanskih shkolah (1940-1960 yy.). Dissert. candidate. ped. Sciences, p. 27. Almaty. 
Uzakbaeva, S. A. (1995). Vospitanie s glubokimi kornaymi. Journal bilim, p.232 Almaty.

Amiraliev, S., \& Seitaliev, K. (1983). Edinstvo vospitaniya i obucheniya, p.182 Almaty.

Ashaiuly, A. (2002). Organizaciya uchebno-vospitatelnoi raboty na nacionalno-pedagogicheskoi osnove (dlya uchenikov nachalnyh klassov): Author's abstract dissertation, p.16. Almaty.

Atutov, P. R., \& Polyakov, B. A. (1985). Rol trudovogo obucheniya v politehnicheskom obrazovanii shkolnikov. Pod redaksii Avericheva, p.128.

Kojahmetova, K. J. (1993). Nekotorye nauchnye i teoreticheskie voprosy issledovaniya narodnoi pedagogiki, p.17, Almaty.

Omar, E. O. (2002). Stanovlenie i razvitie vneshkolnyh uchrejdenii v Kazahstane (1917-1990 yy) dissert. candidate. ped. Sciences, p.32. Almaty.

Tretyakov, P. N., \& Sennovskii I. B. (1997). Tehnologiya modulnogo obucheniya v shkole, p. 352. Moscow. Pod redasii novaya shkola.

Tabyldiev, A. (1991). Narodnaya kazahskaya pedagogika i vospitanie. Kazahskii universitet, p. 213. Almaty.

Tajibaeva, S. G. (2007). Metodika organizacii vospitatelnoi raboty v shkole. Uchebnoe posobie, p. 359. Almaty.

\section{Authors}

Daniarov Talgat candidate of pedagogical sciences. He works at A. Yassawi Kazakh-Turkish International University. He is the author of 77 scientific articles. Among them 25 articles published abroad and 2 of them published in the scientific journals with impact factor. E-mail: shakarim80@mail.ru

Postal address: Kazakhstan, Turkistan, A. Yassawi Kazakh-Turkish International University, B. Sattarkhanov avenue 68 .

Bazarbaev Kanat candidate for PhD. He is the author of 38 scientific articles. Scientific journals of Kazakhstan, Kyrgyzstan, Russia, Poland, Turkey and Hong Kong.

Contact data: 161200, Turkestan, South Kazakhstan Region, the Republic of Kazakhstan Phone: 8701-646-22-95. (72533) 4-09-51. E-mail: Kanat-08@mail.ru

Nyshnova Saltanat candidate of pedagogical sciences. She works at Yassawi Kazakh-Turkish International University. She is the author of 32 scientific articles. Among them 5 articles published abroad and 2 of them published in the scientific journals with impact factor. E-mail: saltanur@mail.ru

Postal address: Kazakhstan, Turkistan, A. Yassawi Kazakh-Turkish International University, B. Sattarkhanov avenue 68 .

Myrzakhanova Akbota - candidate of pedagogical sciences. E-mail: mirbota@mail.ru

Postal address: Kazakhstan, Turkistan, A. Yassawi Kazakh-Turkish International University, B. Sattarkhanov avenue 68 . 